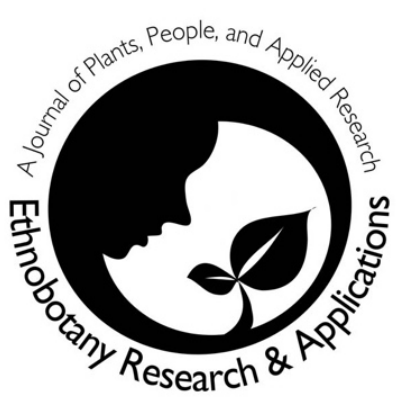

\title{
Traditional use of tarragon I pèrschtròmm (Artemisia dracunculus L., Asteraceae) in the linguistic island of Sappada/PIodn (European Alps, northern Italy)
}

\author{
Chiara Manfrinato, Marco Canella, Nicola M. G. Ardenghi, \\ Filippo Guzzon
}

\section{Research}

\begin{abstract}
Background: Tarragon (Artemisia dracunculus L.) is a perennial herb or subshrub belonging to the Asteraceae family. It is widely used in culinary recipes from several areas of the world for its aromatic properties. This study analyses the traditional use and the cultivation of this crop in the village of Sappada/Plodn, a German linguistic island in north-eastern Italy. Here, the species, vernacularly known as pèrschtròmm, is employed to flavour a sour soft cheese, called saurnshotte.
\end{abstract}

Methods: This paper verifies the taxonomic identity of pèrschtròmm and studies its traditional use in Sappada/Plodn. The gathered information concerned tarragon propagation, cultivation, plant material processing and preparation of saurnshotte. The survey is based on ethnobotanical interviews integrated with literature research.

Results: Tarragon is still cultivated by a dozen inhabitants, but its use on domestic scale for cheese production is almost disappeared. Nevertheless, the recent revival of this tradition is bringing the production of saurnshotte from a domestic scale to a commercial one finding a place in the Sappada economy that is mostly touristic based.

Discussion: tarragon is not a common ingredient in northern Italy culinary tradition and It is interesting to note that the cultivation of this crop is limited to Sappada/Plodn, not occurring in neighbouring villages. This fact supports the connection between Sappada/Plodn with Tyrolean and Carinthian regions, where the village inhabitants are supposed to come from.

Conclusions: The survey verified the taxonomic identity of pèrschtròmm as tarragon, sustaining the identification with herbarium vouchers. The current cultivation and processing of tarragon for saurnshotte production is still a cultural heritage of the linguistic island, even if threatened by the low number of holders of folk knowledge and the commercialization of new tarragon-based products designed ad hoc for tourists' consumption.

\section{Correspondence \\ Chiara Manfrinato*, Marco Canella, Nicola M. G. Ardenghi, Filippo Guzzon \\ * Corresponding author: \\ Via Cesare Battisti 43/A, Sant'Elena (PD) chiaramanfrinato.cm@gmail.com \\ Ethnobotany Research \& Applications 18:5 (2019)}

\section{Riassunto}

Contesto: Il dragoncello (Artemisia dracunculus L.) è una specie erbacea perenne o un arbusto appartenente alla famiglia delle Asteraceae e fa parte della tradizione gastronomica di diverse parti del mondo per via delle sue proprietà aromatiche. II presente studio analizza l'uso e la coltivazione di questa pianta presso un'isola linguistica di ceppo germanico nel nord-est Italia, Sappada (Plodn nella 
lingua locale). In questo luogo il dragoncello, indicato con il termine pèrschtròmm, viene impiegato nella preparazione di un formaggio tipico, una ricotta chiamata saurnshotte.

Materiali e metodi: Questo articolo verifica l'identità tassonomica di pèrschtròmm e indaga il suo attuale utilizzo a Sappada/Plodn. Le informazioni ottenute riguardano coltivazione, propagazione, lavorazione del dragoncello e preparazione della saurnshotte. L'indagine etnobotanica è basata su interviste e ricerca bibliografica.

Risultati: II dragoncello è ancora coltivato da una dozzina di abitanti ma il suo uso su scala domestica per la preparazione del formaggio tipico è quasi scomparso. Tuttavia, la recente riscoperta di questa antica tradizione sta portando la produzione di saurnshotte da una scala domestica a una commerciale, trovando un posto nell'economia di Sappada/Plodn, basata essenzialmente sul turismo.

Discussione: II dragoncello non è un ingrediente tipico della cucina del nord Italia ed è interessante notare come la coltivazione di questa specie sia limitata a Sappada/Plodn senza essere riscontrata nelle aree circostanti. Questo fatto supporta la connessione tra Sappada/Plodn con le regioni di Tirolo e Carinzia, dove si suppone i sappadini affondino le loro radici.

Conclusioni: l'indagine etnobotanica ha confermato l'identità tassonomica di pèrschtròmm, associandola a $A$. dracunculus e supportando l'identificazione con campioni d'erbario. L'attuale coltivazione e lavorazione del dragoncello per la preparazione di saurnshotte è ancora patrimonio culturale dell'isola linguistica, nonostante questa tradizione sia minacciata dal basso numero di depositari delle conoscenze necessarie alla preparazione di saurnshotte e dalla commercializzazione di nuovi prodotti non tradizionali realizzati appositamente per i turisti.

\section{Background}

A shift occurred in the last decades from an agrisilvicultural economy towards a touristic-based one in several areas of the European Alps, and the depopulation of small villages caused the abandonment of traditional agricultural activities in many localities (Bätzing 1996, Tasser et al. 2007). Additionally, the genetic erosion and extinction of local crop landraces has been observed in several alpine areas (Van Der Stege 2012). Linguistic and cultural islands in the Alps have been demonstrated to serve as refuges for crop landraces and neglected crops (Laghetti et al. 2004, Hammer et al. 2007), as in the case of the great diversity of crops species found in the Central-Eastern Alpine home gardens (Vogl and Vogl-Lukasser 2005, Hammer et al. 2015, Vogl-Lukasser \& Vogl 2005). The study-area of the current survey is Sappada (in Italian) or Plodn (in the local German dialect), a village of around 1,300 inhabitants in eastern Dolomites, between the Italian administrative regions of Veneto and Friuli-Venezia Giulia, and bordering Austria. The village territory has an area of just 6200 ha but it has been subject of linguistic and ethnographic studies because some of its inhabitants still speak a specific German dialect linguistically isolated from the neighboring areas (Peratoner et al. 2009). Sappada/Plodn is therefore considered a German linguistic island. Indeed, a hundred of people in the village still speak a Middle High German dialect called sappadino or plodarisch which has also some elements from Old High German. This dialect is considered as surviving from the German spoken mainly in southern and central Germany, Austria and parts of Switzerland during the High Middle Ages (Marcuzzi 1989). The origins of this linguistic island are currently not fully clarified. The main theory about its origin dates its foundation to the early 10th century, with the immigration of German-speaking people from Tyrol, but the germanization of pre-extant Slavic populations or other migration flows from neighboring localities of Carnia (a historical and geographical region of FriuliVenezia Giulia in the province of Udine) probably also occurred (Peratoner 2002; Peratoner et al. 2009).

Several ethnobotanical surveys have been made in home gardens of this area as well as in other related German linguistic islands in Friuli-Venezia Giulia (such as Sauris/Zahre and Timau/Tischlbong) but, up to our knowledge, the use and cultivation of Artemisia dracunculus L. (Asteraceae), has never been reported. Therefore, this paper is the first contribution describing the characteric use of tarragon (in the local Germanic dialect named pèrschtròmm) in Sappada/Plodn and its importance in the village culinary and agricultural traditions.

The main aim of the present paper are to: 1) characterize the use and cultivation of tarragon in Sappada/Plodn and its importance for the cultural identity of this linguistic island; 2) report the traditional knowledge on plant material processing for the production of saurnschotte, the local tarragonbased ricotta cheese; 3) clarify if the tarragon in Sappada/Plodn is declining in cultivation as it happened for several landraces and neglected crops in northern Italy in the last few decades (Pieroni et al. 
2016, Ardenghi et al. 2017) or if, on the other hand, its usage linked to traditional food productions is undergoing a process of revival as it is occurring for many neglected crops in several countries (Barthel et al. 2013).

\section{Materials and Methods}

Interviews were carried out in the municipality of Sappada/Plodn, province of Udine, in the Italian administrative region of Friuli-Venezia Giulia. Interview activity and sampling took place in the months of July and August 2017.

Twenty people (aged between 30 and 65) were interviewed. Five herbarium samples of tarragon from home-gardens were collected with the assent of the growers and stored at the Herbarium
Universitatis Ticinensis (PAV). A semi-structured questionnaire was employed with questions about tarragon cultivation techniques, phenology, biology and usage of this plant. Information about etymology, culinary uses, and cultivation was acquired from the survey of all the available historical and contemporary floristic, linguistic, and culinary literature sources. In past times Sappada/Plodn's inhabitants had commercial relationships with the German linguistic islands of Sauris/Zahre and Timau/Tischlbong where similar dialects are spoken (Societat Filologjiche Furlane 1994) as shown in Figure 1. The cultivation and use of tarragon in those areas as well as in Romance languages-speaking neighbor areas was investigated.

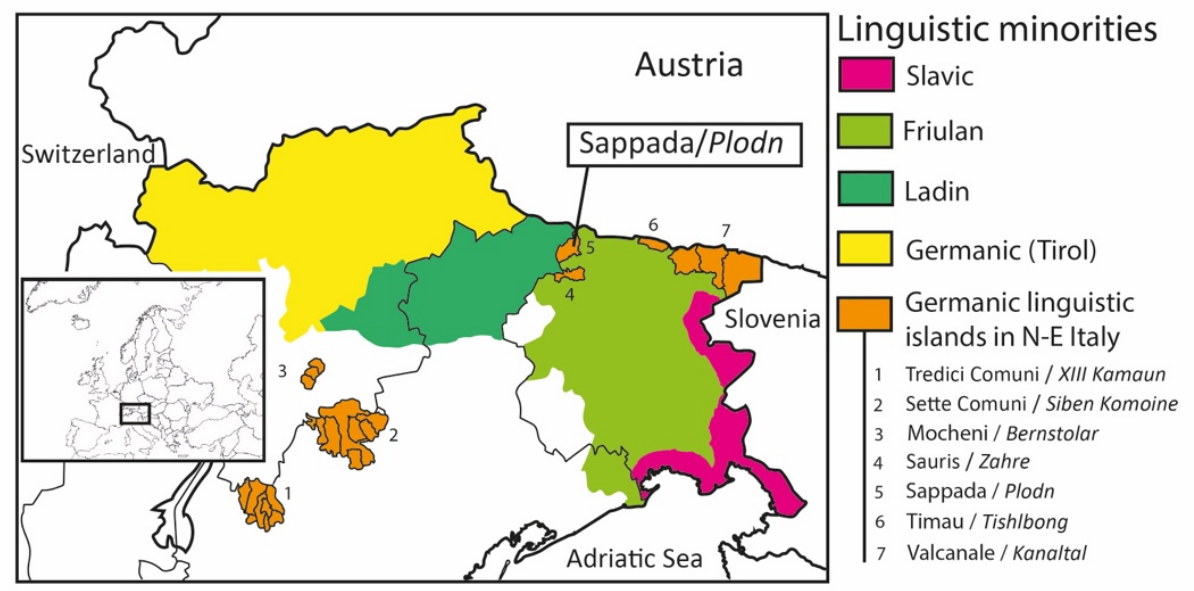

Figure 1. Study area and the recognized linguistic minorities in North East Italy; German linguistic islands (orange layer) belong to the same linguistic families but the dialects and their historic origins are different.

\section{Results}

Taxonomic identity of pèrschtròmm

Artemisia dracunculus L. (tarragon, estragon) is a subshrub or perennial herb belonging to the Asteraceae family. It has significant variability in morphology, anatomy, fertility, phytochemical constituents and ploidy, revealed by the occurrence of different cytotypes expressing divergent phytochemical profiles (Obolskiy et al. 2011). In the course of centuries, conflicting taxonomic treatments emerged, considering tarragon a complex of species (see e.g. Poljakov 2000) or a single species divided into multiple varieties (see e.g. Yourun et al. 2011).
Tarragon has a wide natural distribution range, spanning from North America to most the Asian continent and part of eastern Europe (Ukraine), where it mainly grows in steppes, subalpine meadows and waste areas, on saline-alkaline soils. In most Europe it is recorded as a casual or naturalized alien (Poljakov 2000, Greuter 2006+, Eisenman \& Struwe 2011, Yourun et al. 2011).

On horticultural grounds, $A$. dracunculus cultivars are assembled into two cultivar groups (sometimes considered as two simple cultivars or even as distinct varieties, see Oboloskyi et al. 2011): 1) French Tarragon Group (syn. A. dracunculus var. sativa Besser, German Tarragon Group), comprising tetraploid $(2 n=36)$ cultivars, which seldom produce 
normal flowers and never viable seeds, its propagation being usually by stem or rhizome cuttings, and characterized by very fragrant leaves. It includes the most important spice cultivars (such as 'Epicure') and is mostly cultivated in Europe and the United States. The main component of its essential oil is methyl chavicol; 2) Russian Tarragon Group [syn. A. dracunculus var. glauca (Pall. ex Willd.) Besser, A. dracunculus var. inodora (Willd.) Besser, nom. illeg., A. redowskyi Ledeb.], comprising less fragrant and decaploid $(2 n=90)$ cultivars, more closely related to the wild forms, regularly flowering and producing viable seeds; usually propagated by seed, it is mainly cultivated in northern Asia. The main components of its essential oil are elemicin and sabinene (PlantUse English contributors 2016).

Tarragon is primarily a crop of temperate climates, employed as a spice in several traditional cuisines to flavor different kind of products, such as meat, fish, drinks and sauces, and as a medicinal herb in parts of the world, e.g. North and South America, Europe, Indian Subcontinent, Southeast Asia, Northern and Southern Africa (Jeffrey 1995; Oboloskyi et al. 2011; Voigt 2000). Many cook books report tarragon as main ingredient or essential aroma for typical dishes such as stuffed vegetables in Afghanistan and Armenia, chicken meat in Georgia, fish dishes in Dhekelia, steer meat in Austria and two famous sauces: the Béarnaise and the Tartare sauces from France (Mattei 2001; McCormick 1990).

Plants sampled during this study (five specimens, see Table 1) are characterized by leaves with a strong spicy licorice flavor, capitula with sterile florets, and are propagated only vegetatively. On the basis of these elements, they can be classified as belonging to the French Tarragon Group. $A$. dracunculus is unknown as a wild plant in Italy (Galasso et al. 2018) and was indeed not found growing spontaneously in the study area.

\begin{tabular}{|c|c|c|}
\hline Location & Site notes & $\begin{array}{l}\text { Georeferred } \\
\text { position } \\
\text { (WGS84) }\end{array}$ \\
\hline $\begin{array}{l}\text { Sappada/Plodn } \\
\text { (BL), Cretta } \\
\text { hamlet }\end{array}$ & $\begin{array}{l}\text { Ethnographic } \\
\text { Museum's } \\
\text { display } \\
\text { garden }\end{array}$ & $\begin{array}{l}46^{\circ} 34^{\prime} 16.28^{\prime \prime} \mathrm{N} \\
12^{\circ} 42^{\prime} 50.52^{\prime \prime} \mathrm{E}\end{array}$ \\
\hline $\begin{array}{l}\text { Sappada/Plodn } \\
\text { (BL), Cima } \\
\text { hamlet }\end{array}$ & $\begin{array}{l}\text { Private home- } \\
\text { garden }\end{array}$ & $\begin{array}{l}46^{\circ} 34^{\prime} 11.35^{\prime \prime N} \\
12^{\circ} 43^{\prime} 21.68 " \mathrm{E}\end{array}$ \\
\hline $\begin{array}{l}\text { Sappada/Plodn } \\
(\mathrm{BL}) \text {, Cima } \\
\text { hamlet }\end{array}$ & $\begin{array}{l}\text { Ethnographic } \\
\text { Museum's } \\
\text { display } \\
\text { garden }\end{array}$ & $\begin{array}{l}46^{\circ} 34^{\prime} 8.71 " \mathrm{~N} \\
12^{\circ} 43^{\prime} 14.95 " \mathrm{E}\end{array}$ \\
\hline
\end{tabular}

\begin{tabular}{|l|l|l|}
\hline $\begin{array}{l}\text { Sappada/Plodn } \\
\text { (BL), Ecke hamlet }\end{array}$ & $\begin{array}{l}\text { Private home } \\
\text { garden }\end{array}$ & $\begin{array}{l}46^{\circ} 34^{\prime} 12.09^{\prime \prime} \mathrm{N} \\
12^{\circ} 42^{\prime} 8.86^{\prime \prime} \mathrm{E}\end{array}$ \\
\hline $\begin{array}{l}\text { Sappada/Plodn } \\
\text { (BL), Lerpa } \\
\text { hamlet }\end{array}$ & Private home & $46^{\circ} 34^{\prime} 6.70^{\prime \prime} \mathrm{N}$ \\
garden & $12^{\circ} 40^{\prime} 11.65 " \mathrm{E}$ \\
\hline
\end{tabular}

\section{Linguistic and ethnographic notes}

It is interesting to note that the Tyrolian word "Schotte" corresponds to the German "Topfen" and the German "Quark" and "Fromage frais" in French, a very young, mild fresh cheese. Sappada/Plodn's inhabitants traditionally link their origin with a village called Luggau, located in the border between the German region of Tyrol and Carinthia (Baldin et al. 2017). In order to remember the exodus from TyrolCarinthia, since 1804 Sappada/Plodn's inhabitants undertake an annual pilgrimage that join them with their old country. This symbolic and religious rite is intended to avert livestock illness and represents another connection with south German peoples. The widespread presence of soft cheese with tarragon (but also other aromatic herbs such as parsley and sage) or tarragon-based dishes in southern Germany and France (Fox 1970; Pouriau 1872) suggests this use probably transferred to the linguistic island of Sappada/Plodn from northern Europe. Another hypothesis about saurnschotte origin was proposed in a study that dates back to 1938 but published only in 2005 (Bruniera 2005), in which a "Zaure sotte" is mentioned and defined as "ricotta cheese from Sauris". No trace of saurnshotte has been found in Sauris, the nearby linguistic island, by authors. Maria Bruniera (2005) accurately debated the linguistic and etymological aspects but strangely identified pèrschtròmm with another Asteraceae species, Anacyclus pyrethrum (L.) Lag. (Roman pellitory or Mount Atlas daisy). At the same time, Giuseppe Fontana (1966) identified "pestrum", a variation of the word pèrschtròmm, as Hyssopum officinalis L. subsp. officinalis (hyssop). In our surveys the interviewed growers used pèrschtròmm to refer only to $A$. dracunculus.

\section{Botanical uses}

Saurnschotte is a typical soft ricotta cheese with the addition of tarragon. The translation from sappadino language is literally "acid ricotta cheese". In fact, the strong licorice taste of the aromatic herb added in the last phases of the preparation covers the acidity of milk caused by the first phases of souring. The final result is a soft cheese, usually consumed with boiled potatoes, characterized by strong flavor and white color (Figure 2d). Only four of the interviewed persons knew how to make saurnshotte. One saurnschotte producer with commercialization has been found located in a farm in Sappada/Plodn. This farm is the only place where saurnshotte is sold, 
since 2011. The product is sold directly to the costumers.
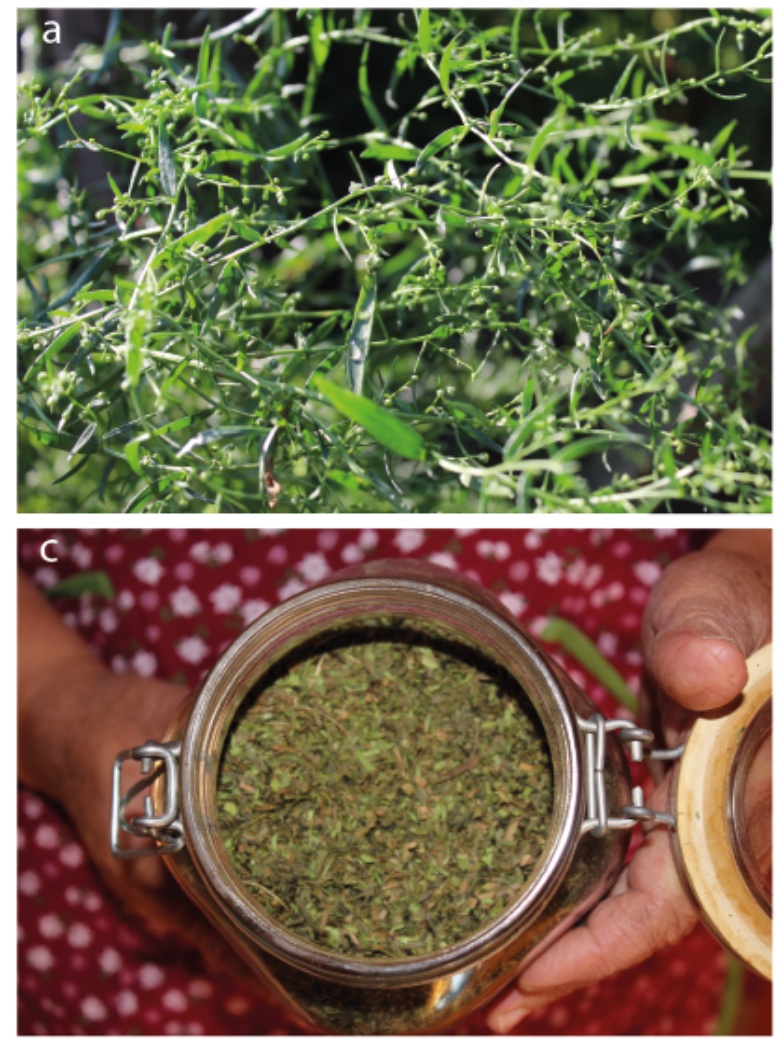

Tarragon used for saurnschotte production is cultivated on a domestic scale in the farm by the owner and his family (Figure 2a-b) or obtained through a net of collaborators in Sappada/Plodn.
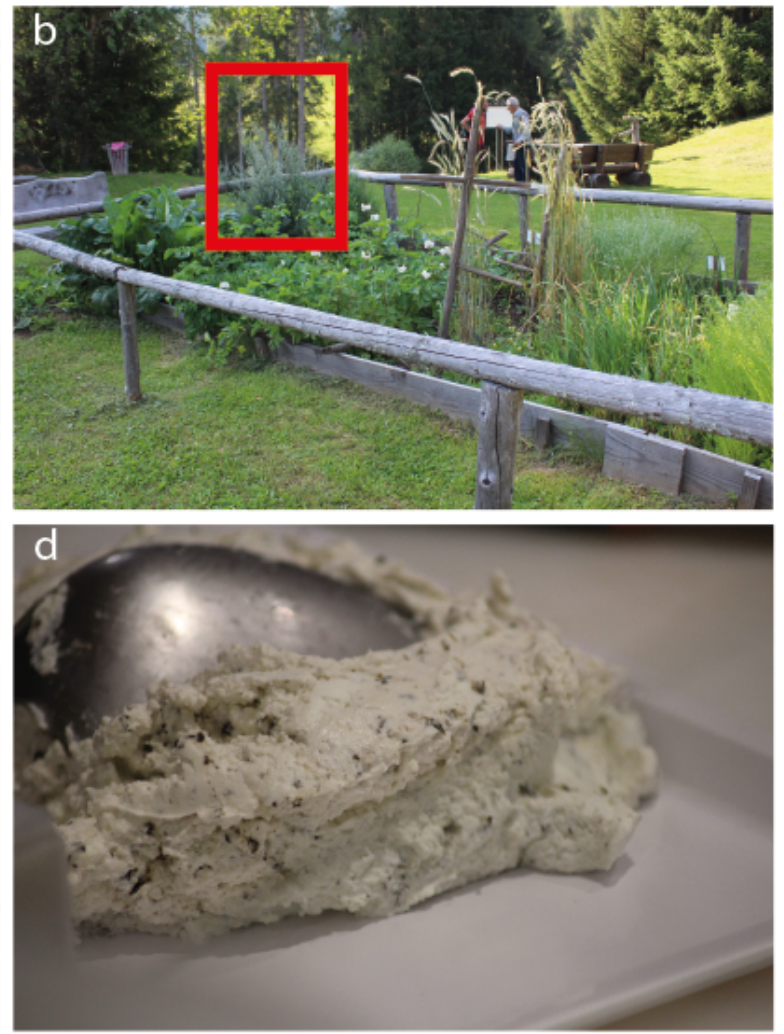

Figure 2 (a) Tarragon/pèrschtròmm plant in the Luigi Kratter's garden, late July; (b) The display garden of Ethnographic Museum "Giuseppe Fontana" and typical corner position occupied by Tarragon; (c) Dried plant material collected in summer 2016 by Maria Kratter and ready to the use; (d) Saurnschotte produced in the dairy 'Plodarkelder'.

The harvest obtained by the farm reaches currently seven jars of one liter each of ground plant material (represented by leaves only) per year, with an increasing trend. The final product of the farm is around 100 kilograms of saurnshotte per year.

Two growers currently cultivate tarragon on a small scale to produce saurnschotte for their own consumption. The number of growers still cultivating this spice is estimated around some multiple of ten. No cultivation and/or use of tarragon has been found outside the area of the linguistic island of Sappada/Plodn and this confirms the strong link between the use of tarragon for saurnshotte production and the inhabitants of Sappada/Plodn. Recent uses of this plant in the linguistic island (such as in aromatized spirits, ice creams, infusions and perfume for soaps) have been detected in many local markets. These products have been recently designed for tourists and there is no trace of them in ancient Sappada/Plodn traditions. In fact, the major part of these products is imported or produced in loco with imported tarragon.

\section{Pèrschtròmm cultivation and processing}

Currently there is no large-scale cultivation of tarragon in Sappada/Plodn, and no documents or witness suggest there was in the past. Growers interviewed reported that every family native to Sappada/Plodn used to have at least one tarragon plant in their garden for domestic production of saurnshotte. A dozen, a few dozen maximum, of native families not producing saurnschotte anymore still have one tarragon plant in their garden, maintaining past habits.

Tarragon is usually planted in the corner of the garden because, if placed in the middle, it could invade the space used for the cultivation of other 
edible plants (usually cabbages or lettuce), due to its rapid growth during the summer.

Plants grow to the height of $70-100 \mathrm{~cm}$ and then are harvested at the end of the summer, before the sterile blooming. In this season the concentration of aromatic substances reaches its peak and the processing of plant material is facilitated by the absence of flowers. Only leaves are kept for saurnshotte production, the rest of plant material is discarded. Traditionally the harvest was made between the two Catholic religious recurrences of Assumption and Nativity of Mary (15 of August and 8 of November), but now it occurs earlier (usually from July) according to the phenology shift of this species in response to the warmer summers of last decades. After the harvest, the plant does not die and vegetative growth restarts in spring (April or May, depending on the duration of the snow covering); plants are propagated vegetatively by means of stem cuttings. In spring, after the snowmelt (between the end of April and the beginning of May), sprigs are cut and transplanted in tilled soil where they easily take roots. In past time, saurnschotte was produced only during summer, especially early in the season, when the milk production reached its maximum. Consequently, the tarragon used had been harvested the previous year. In the past, plant material was maintained dried (Figure 2c); at present time, it is dried, or ground and salted.

When the ricotta cheese is ready, ground tarragon is added. The saurnschotte was kept in dry cellars, in wood bowls ("milchhovn" in dialect) covered with a kitchen rag.

\section{Discussion}

The use of tarragon for saurnschotte preparation is definitively confined to the linguistic enclave of Sappada/Plodn. Tarragon is still well represented and propagated in the gardens of Sappada/Plodn, but its utilization for saurnschotte production for domestic use is declining. The presence of tarragon in gardens is probably due to the persistence of past habits and traditions, but plants are barely utilized for new uses (spirit or meat aromatization) not linked with past traditions. For sure, tarragon plants have an ornamental value too. Clearly the pèrschtròmm production is currently in a transition phase from domestic to commercial production. Very few families still produce saurnschotte and only elderly people (older than 65-70 years) still hold the necessary knowledge. On the other hand, for the first time the local cheese is produced in a professional diary for commercialization with a permission from
Italian agency for health and food security (ULSS). The low production still impedes sale in local markets, and at present saurnshotte is sold only by the diary of the town. Probably it will be available in nearby markets in future years. In this case entrepreneurship and commercialization to tourists seem to boost the persistence of traditional cultivation and use of the pèrschtròmm as revealed for other crops and crop cultivars in north Italy (Ardenghi et al. 2017; Ardenghi et al. 2018). However, the launch of new tarragon-based products such as aromatized spirits (Figure 3), bars of soap, ice-creams and herbal tisanes, suggests that a development of ancient traditions may be occurring: many of these products are indicated as "typical Sappada/Plodn products" but there is no historical relationship with the linguistic island's traditions, and they are not made with local tarragon. It is interesting to note that several species of the genus Artemisia have a documented antifungal activity (Kordali et al. 2005). In recent times, (Raiesi et al. 2012) suggest that essential oils of tarragon could be employed for cheese conservation due to its antibacterial effect on two important pathogenic bacteria (Staphylococcus aureus Rosenbach 1884 and Escherichia coli Migula 1895 (Castellani \& Chalmers, 1919)). In spite of this fact, none of the locals interviewed mentioned a conscious use of the plant connected with the cheese conservation.

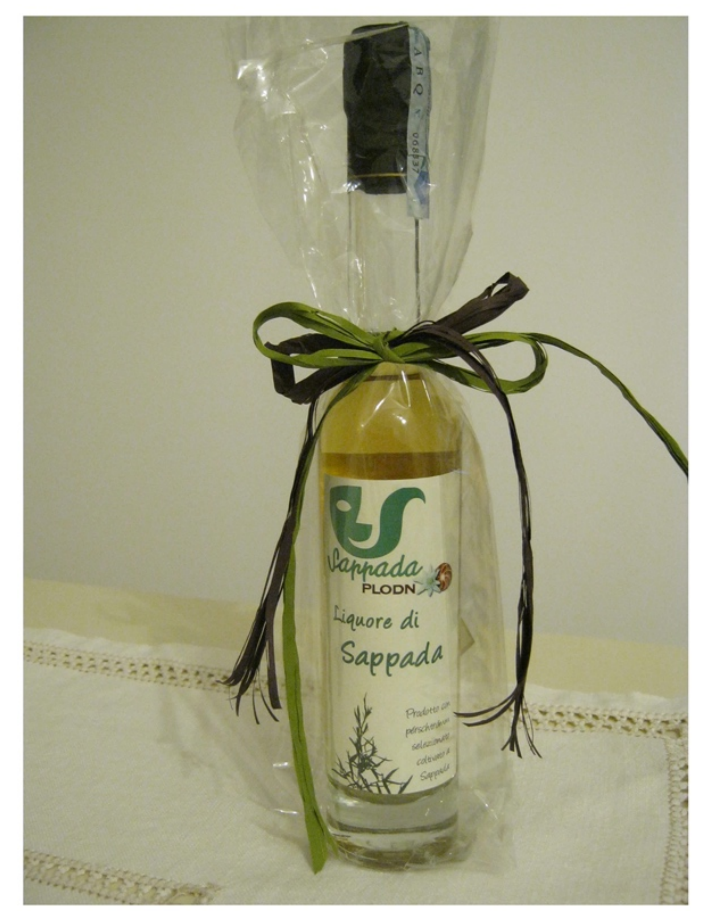

Figure $3 \mathrm{~A}$ bottle of tarragon-aromatized grappa, an example of merchandise designed for tourists' consumption. 


\section{Conclusions}

The knowledge of plant material processing for the local ricotta cheese (saurnschotte) production is still present in the Germanic linguist island of Sappada/Plodn. The French Tarragon cultivar, strongly aromatic but sterile, is still cultivated by inhabitants and propagated with stem cuttings. The use of this botanical in saurnschotte production decreased in the last decades and only one family still produce it for self-consumption. On the other hand, we recorded a recent revival of this ancient tradition, with the consequent transition from a domestic scale production to a diary/commercial one. In this case tourist interest in local products seems to boost resilience of local knowledge, cultural identity and conservations of plant genetic resources. At the same time the commercial dimension raises the problem of inauthentic tarragon-based products designed ad hoc for tourists' consumption.

\section{Declarations}

List of abbreviations: No abbreviations were used in the article.

Ethics approval and consent to participate: the survey was performed following the code of Ethics of the International Society of Ethnobiology (ISE) and in compliance with the Protocol of Nagoya on Access and Benefit Sharing if appropriate.

Consent for publication: Informants' sensitive data are not included in the publication.

Availability of data and materials: Datasets were not deposited in public repositories.

Competing interests: The authors declare that they have no competing interests.

Funding: The authors received no funding for this work.

Authors contributions: Chiara Manfrinato conceived and performed the field survey, collected the plant material, analyzed data and literature sources, authored and approved final draft; Marco Canella conceived and performed the field survey, collected the plant material, analyzed data and literature sources, designed maps and figures, authored and approved final draft; Nicola M. G. Ardenghi: analyzed data and literature sources, identified the plant material, curated the herbarium vouchers, authored and approved final draft; Filippo Guzzon analyzed data and literature sources, designed maps and figures, authored and approved final draft;

\section{Acknowledgements}

Ethnological information about the origin of Sappada/Plodn and his inhabitants were provided through literature sources and the contribution of the curator of Ethnographic Museum "Giuseppe Fontana", Marcella Benedetti. We thank Luigi and Maria Kratter, Sara and Marta Piller Roner of the dairy "Plodarkelder" (bg.ta Fontana, 32047 Sappada, BL) for the time they dedicated us and for the permission to collect herbarium vouchers from their gardens.

\author{
Author details: \\ Chiara Manfrinato $^{1^{*}}$, Marco Canella ${ }^{2}$, Nicola M. G. \\ Ardenghi², Filippo Guzzon ${ }^{2}$ \\ ${ }^{1}$ Via Cesare Battisti 43/A, Sant'Elena (PD), Italy \\ 2 Department of Earth and Environmental Sciences, \\ University of Pavia, I-27100 Pavia, Italy \\ * Corresponding author: \\ chiaramanfrinato.cm@gmail.com
}

\section{Literature cited}

Ardenghi NMG, Ballerini C, Bodino S, Cauzzi P, Guzzon F. 2017. Lándar, Lándra, Barlánd (Bunias erucago L.): a neglected crop from the Po Plain (Northern Italy). Economic Botany 20(10):1-8.

Ardenghi NMG, Rossi G, Guzzon F. 2018. Back to beaked: Zea mays subsp. mays Rostrata Group in northern Italy, refugia and revival of open-pollinated maize landraces in an intensive cropping system. PeerJ 6. DOI: e5123.

Baldin S, Zago M, Beccalli C, Corvo P, De Salvo P, Delli Zotti G, Fadda A, Fassino G, Favalli S, Ferri D, Guerra P, Karlsen P, Kranjcevic J, Lavarini R, Vukadin IM, Monego D, Perri A, Piciocchi C, Porcelli G, Pupo GR, Righetti N, Romita T, Savelli A, Scramaglia R, Stener F, Tamma M, Tonazzi N, Urpis O, Zanetti C. 2017. Luoghi dell'anima, anime in cammino. Riflessioni su eredità culturale e turismo religioso. Angeli Editore, Milan, Italy.

Barthel S, Crumley C, Svedin U. 2013. Biocultural refugia - Safeguarding diversity of practices for food security and biodiversity. Global Environmental Change 23(5):1142-1152.

Bätzing W, Perlik M, Dekleva M. 1996. Urbanization and depopulation in the Alps (with 3 Colored Maps). Mountain Research and Development 16:335-350.

Bruniera M. 2005. Il dialetto tedesco nellisola alloglotta di Sappada. Forum Editore, Udine, Italy.

Eisenman SW, Struwe L. 2011. The global distribution of wild tarragon (Artemisia dracunculus L.; Asteraceae) cytotypes with twenty-seven new 
records from North America. Generic Resources and Crop Evolution 58(8): 1199-1212.

Fontana G. 1966. Addio vecchia Sappada! Storia, leggende, case, attrezzi, usi, costumi, cibi, abiti, dialetto, occupazioni, amenità, folclore di un tempo Iontano. Castaldi Editore, Feltre, Italy.

Fox HM. 1970. Gardening with herbs for flavor and fragrance. Dover Publications Inc., New York City, New York.

Galasso G, Conti F, Peruzzi L, Ardenghi NMG, Banfi E, Celesti-Grapow L, Albano A, Alessandrini A, Bacchetta G, Ballelli S, Bandini Mazzanti M, Barberis G, Bernardo L, Blasi C, Bouvet D, Bovio M, Cecchi L, Del Guacchio E, Domina G, Fascetti S, Gallo L, Gubellini L, Guiggi A, lamonico D, Iberite M, Jiménez-Mejías $P$, Lattanzi $E$, Marchetti $D$, Martinetto, Masin RR, Medagli P, Passalacqua NG, Peccenini S, Pennesi R, Pierini B, Podda L, Poldini L, Prosser F, Raimondo FM, Roma-Marzio F, Rosati L, Santangelo A, Scoppola A, Scortegagna S, Selvaggi A, Selvi F, Soldano A, Stinca A, Wagensommer RP, Wilhalm T, Bartolucci F. 2018. An updated checklist of the vascular flora alien to Italy. Plant Biosystems 152(3): 556-592.

Greuter W. 2006 (onwards) Compositae (pro parte majore). Compositae. Edited by Greuter W, RaabStraube E. Euro+Med Plantbase - the information resource for Euro-Mediterranean plant diversity.

Hammer K, Miceli F, Cifarelli S, Laghetti G. 2007. Sauris (Zahre), a cultural and linguistic island in Carnia (Italy). In: Proceedings of the 17th Eucarpia Genetic Resources Section Meeting, Plant Genetic Resources of Geographical and "other" islands. Edited by Bullitta S. CNR-ISPAAM, Castelsardo, Italy, Pp. 185-192

Jeffrey C. 1995. Compositae systematics 19751993. Developments and desiderata. In Advances in Compositae Systematics. Edited by Hind DJN, Jeffrey C, Pope GV. Royal Botanic Gardens, Kew, UK, Pp 7-21.

Kordali S, Kotan R, Mavi A, Cakir A, Ala A, Yildirim A. 2005. Determination of the chemical composition and antioxidant activity of the essential oil of Artemisia dracunculus and of the antifungal and antibacterial activities of Turkish Artemisia absinthium, Artemisia dracunculus, Artemisia santonicum, and Artemisia spicigera essential oils. Journal of Agriculture and Food Chemistry 53(24):9452-8.

Laghetti G, Miceli F, Cifarelli S, Hammer K. 2004. Collection of crop genetic resources in Italy. Plant genetic resources newsletter 152: 82-87.
Marcuzzi G. 1989. Demographic characteristics of German linguistic islands of the Southern Alps (Italy and Tessin, Switzerland). Anthropologischer Anzeiger 47(2): 109-127.

Mattei R. 2001. Manuale di nutrizione clinica. Franco Angeli, Milan, Italy.

McCormick MJ. 1990. A taste for Tarragon. The Herb Companion magazine. New York City, New York.

Obolskiy D, Pischel I, Feistel B, Glotov N, Heinrich M. 2011. Artemisia dracunculus L. (Tarragon): A Critical Review of Its Traditional Use, Chemical Composition, Pharmacology, and Safety. Journal of Agricultural and Food Chemistry 59 (21): 1136711384.

Peratoner A, Isabella D, Benedetti M, Pachner G, lanniello C, Lorenzini C, Polencic A, Armano L. 2009. Sappada/Plodn. Identità culturale di un'isola linguistica alle Sorgenti del Piave. Forum Editore, Udine, Italy.

Peratoner A. 2002. Sappada/Plodn. Storia, etnografia e ambiente naturale. Tiziano Editore, Pieve di Cadore, Italy.

Pieroni A, Pawera L, Shah GM. 2016. Gastronomic ethnobiology. In Introduction to ethnobiology. Edited by Albuquerque UP, Nóbrega RR. Springer, Dordrecht, Holland, Pp 53-62.

PlantUse English contributors. 2016. Artemisia dracunculus (PROSEA) Avaliable from: https://uses.plantnet-

project.org/e/index.php?title=Artemisia_dracunculus _(PROSEA)\&oldid=222083. Retrieved 17 December 2018.

Poljakov PP. 2000. Genus 1550. Artemisia L. In Flora of the USSR. Volume XXVI. Compositae. Tribes Anthemidae, Senecioneae, and Calenduleae. Edited by Schischkin BK, Bobrov EG. Smithsonian Institution Libraries, Washington D.C, Pp 404-600.

Pouriau AF. 1872. La laiterie: art de traiter le lait, de fabriquer le beurre et les principaux fromages français et étrangers. Librairie Audot, Paris, France.

Raeisi M, Tajik H, Razavi RS, Maham M, Moradi M, Hajimohammadi B, Naghili H, Hashemi M, Mehdizadeh T. 2012. Essential oil of tarragon (Artemisia dracunculus) antibacterial activity on Staphylococcus aureus and Escherichia coli in culture media and Iranian white cheese. Iranian Journal of Microbiology 4(1):30-4.

Societat filologjiche furlane. 1994. In Guart: anime e contrade della Pieve di Gorto: 71n Congres, 18 Setembar. Edited by Manlio Michelutti. Udine, Italy, Pp. 685. 
Tasser E, Walde J, Tappeiner U, Teutsch A, Noggler W. 2007. Land-use changes and natural reforestation in the Eastern Central Alps. Agriculture, Ecosystem and Environment 118: 115-129.

Van der Stege C, Vogl-Lukasser B, Vogl CR. 2012. The role of homegardens in strengthening socialecological resilience: case studies from Cuba and Austria. In Resilience and Cultural Landscape. Edited by Plielinger T, Bieling C. Cambridge University Press, Cambridge, UK.

Voigt CE. 2000. A Study of Propagation of French Tarragon, Artemesia Dracunculus (L.), Var. sativa by Stem-tip Cuttings. Doctoral dissertation, University of Illinois at Urbana-Champaign.

Vogl-Lukasser B, Vogl CR. 2005. Ethnobotanical Research in Homegardens of Small Farmers in the Alpine Region of Osttirol (Austria): Photo Essay. Ethnobotany Research and Applications 3: 79-97.

Yourun L, Humphries CJ, Gilbert MG. 2011. 151. Artemisia Linnaeus. In Flora of China Volume 20-21 (Asteraceae). Edited by Wu ZY, Raven PH, Hong DY. Science Press, Beijing, Cina and Missouri Botanical Garden Press, St. Louis, Missouri, Pp 676737. 